\title{
Correction to: Theory, Evidence, and Policy on Dual-Class Shares: A Country-Specific Response to a Global Debate
}

\author{
Aurelio Gurrea-Martínez ${ }^{1}$
}

Published online: 17 May 2021

(c) T.M.C. Asser Press 2021

\section{Correction to: European Business Organization Law Review https://doi.org/10.1007/s40804-021-00212-4}

The article Theory, Evidence, and Policy on Dual-Class Shares: A Country-Specific Response to a Global Debate written by Aurelio Gurrea-Martinez, was originally published electronically on the publisher's internet portal on 13 April 2021 without open access. With the author(s)' decision to opt for Open Choice the copyright of the article changed on 27 April 2021 to (C) The Author 2021 and the article is forthwith distributed under a Creative Commons Attribution.

This article is licensed under a Creative Commons Attribution 4.0 International License, which permits use, sharing, adaptation, distribution and reproduction in any medium or format, as long as you give appropriate credit to the original author(s) and the source, provide a link to the Creative Commons licence, and indicate if changes were made. The images or other third party material in this article are included in the article's Creative Commons licence, unless indicated otherwise in a credit line to the material. If material is not included in the article's Creative Commons licence and your intended use is not permitted by statutory regulation or exceeds the permitted use, you will need to obtain permission directly from the copyright holder. To view a copy of this licence, visit http://creativecommons.org/licen ses/by/4.0/.

Publisher's Note Springer Nature remains neutral with regard to jurisdictional claims in published maps and institutional affiliations.

The original article can be found online at https://doi.org/10.1007/s40804-021-00212-4.

Aurelio Gurrea-Martínez

aureliogm@smu.edu.sg

1 Assistant Professor of Law, Singapore Management University, Singapore, Singapore 